\title{
Sustainability in Higher Education: Perceptions of Social Responsibility among University Students
}

\author{
Younghan Jung ${ }^{1, * \mathbb{D}}$, Kayoung Park ${ }^{2}$ and Junyong Ahn ${ }^{3} \mathbb{C}$ \\ 1 Department of Engineering Technology, Old Dominion University, Norfolk, VA 23529, USA \\ 2 Department of Mathematics and Statistics, Old Dominion University, Norfolk, VA 23529, USA; \\ kypark@odu.edu \\ 3 Department of Mechanical and Civil Engineering, Florida Institute of Technology, \\ Melbourne, FL 32901, USA; jahn@fit.edu \\ * Correspondence: yjung@odu.edu
}

Received: 7 January 2019; Accepted: 6 March 2019; Published: 11 March 2019

\begin{abstract}
Many construction-related training and education programs in the United States have now embraced the concept of sustainability, offering sustainable construction courses that highlight sustainable design and construction practices. These courses have mainly focused on green building strategies for the design and construction of built environments and indoor environmental quality necessary for students' knowledge enhancement and career development. This study examined the effect of sustainability course on students' knowledge as well as their perceptions of social responsibility and sustainable behaviors. Data were collected by conducting a survey from construction related programs in U.S. universities. Students were categorized based on their experience of taking such course(s), and results were compared in terms of their environmental concerns, objective and subjective knowledge, and sustainable consumer behaviors by conducting independent two-sample $t$-tests. The purpose of this study was to examine sustainable behaviors and social responsibility perceptions among U.S. university students enrolled in construction-related courses. The results indicated that environmental concern and sustainable consumer behavior scores were significantly lower among students who had taken the course than those who had not. Both objective and subjective knowledge scores were relatively low. There was no difference between the two groups in objective knowledge scores and unexpectedly, subjective knowledge was significantly lower among students who had taken the course than those who had not. The findings of this study provide implications for sustainability curriculum development that can enhance students' learning experience.
\end{abstract}

Keywords: sustainability education; sustainable construction education; social responsibility; sustainable consumer behavior

\section{Introduction}

Since the introduction of the concept of sustainable development in 1987 by World Commission on Environment and Development (Strategic Imperatives-UN 1987), sustainability has been used as a successful approach to shaping the international agenda and the international community's attitude towards economic, social, and environmental development. Facing the challenges posed by global environmental change, a global research platform, the Future Earth, was established in 2015 by the United Nations. According to Future Earth (2014), it is necessary to create a new approach that can link various disciplines from social sciences to natural sciences and establish a global innovation system as global sustainability threats are interconnected. It suggests that all stakeholders should actively participate in the process of developing a holistic and interdisciplinary approach to tackle the 
challenges. Sustainability has become a crucial issue for organizations in recent years, and increasingly, companies across various industries are embracing the concept by implementing sustainability initiatives to enhance the environment as well as their own competitiveness (Rusinko 2007).

Reflecting current trends of sustainable development in the industry, many higher educational institutions in the United States have integrated sustainability into their curricula (Kevern 2011). Some U.S. universities are integrating sustainability by creating a new major, minor, program, or concentration in this area (e.g., St. Petersburg College-Bachelor of Applied Science in Sustainability Management; UC Irvine-Minor in Global Sustainability; George Washington University-Master of Public Health, Environmental and Occupational Health Focus; Northeastern University-MBA Sustainability Concentration; Johns Hopkins University-Master of Science in Environmental Science and Policy). However, a greater number of programs are implementing sustainability with a narrower focus by developing a standalone course within an existing program (Rusinko 2010).

Many studies in the past several years have examined ways to integrate sustainability in higher education (e.g., Benn and Dunphy 2009; Figueiró and Raufflet 2015; Holm et al. 2015; Lidgren et al. 2006; Lozano 2006; O’Byrne et al. 2015; Roome 2005; Rusinko 2010; Sammalisto and Lindhqvist 2008); however, considering the growing number of U.S. university programs developing sustainability courses, there seems to be a relative shortage of studies that examine the effectiveness of these courses and assessment of student outcomes. Moreover, there is a lack of sustainability education research within the field of engineering and construction despite the rising awareness of sustainability topics in this industry domain.

The purpose of this study was to examine sustainable behaviors and social responsibility perceptions among U.S. university students enrolled in construction-related courses. Social responsibility can be defined as a set of obligations an individual or organization "has to protect and enhance the society in which it functions" (p. 127) (Davidson and Griffin 2000). In an attempt to measure the effectiveness of sustainable construction courses, this study categorized students based on their experience of taking the course and compared the results in terms of their level of environmental concern, objective and subjective knowledge related to the course content, and sustainable consumer behaviors. Particularly, while the importance of sustainable education in the engineering and construction field is highlighted in several published studies, how sustainable education in university level affects sustainable consumer behavior is not addressed. Previous studies have suggested that an individual's knowledge or awareness about sustainability issues has an effect on engaging in sustainable purchase behaviors (e.g., Aertsens et al. 2011; Bamberg and Möser 2007). Thus, this study examined whether sustainable education has a positive influence on performing sustainable behaviors, not limiting the notion to engaging in sustainable practices as industry professionals but expanding it to performing other general behaviors including sustainable purchase behaviors as an individual consumer.

\section{Literature Review}

Since the United States Green Building Council (USGBC) launched Leadership in Energy and Environmental Design (LEED) version 1.0 in 1998 and version 2.0 in 2000, the certification system has grown to include a portfolio of nine rating system products that serve specific market sectors in the construction industry (Richards 2012). LEED has grown to become the world's most widely used green building rating system, with nearly 80,000 projects participating in LEED across 162 countries, including more than 32,500 certified commercial projects (U.S. Green Building Council 2015).

In accordance with the trend in the construction industry, an increasing number of construction-related programs in the United States are embracing the concept of sustainability, offering sustainable construction courses that highlight sustainable design and construction practices. These courses have mainly focused on green building strategies for design and construction of built environments, such as site selection, water efficiency, energy, and materials and resources, and indoor environmental quality for students' career development and technical knowledge, 
rather than politics, regulations, green movement, and social responsibility. The M.E. Rinker, Sr. School of Building Construction at the University of Florida that established the first USGBC student chapter in 1998 applied its sustainability educational objectives through 10 major instructional areas (Sullivan and Walters 2013). Among the 10 major instructional areas, only one area covers ethics in construction while other instructional areas cover LEED design criteria and construction strategies such as Building Information Modeling (BIM) to measure energy and water efficiency, the LEED system, and the LEED scorecard to evaluate the sustainability of a design, site development strategies, and so on (Sullivan and Walters 2013).

Application of sustainability embraces technological, environmental, economic, and social factors. Sustainability can be achieved by active participation from professionals in different fields (Libra 2007). An integrated approach by professionals from different areas can provide solutions for the sustainability problems that our society caused (Mihelcic et al. 2003). There were various initiatives to integrate sustainable education transversally within university degree programs (Soria et al. 2013).

Similar to most engineering intensive program for the career development in higher education in the United States, sustainable construction education in Europe is generally centered on developing the ability to apply current knowledge of sustainable building and adapt to emerging applications of mathematics, science, engineering, and technology. Soria et al. (2013) suggest the introduction of sustainable development as a transversal skill for each thematic unit of the class that leads to completely modifying the content. An implementation of the proposed methodology by Soria et al. (2013) was incorporated into a construction engineering department course in a Spanish university to demonstrate the value of including sustainable development education transversally to cover technological, environmental, and social aspects of the sustainability. From the surveys taken at the end of the course, the results showed positive responses from the students who took the transversal course. After completion of the course, students answered that awareness of the current sustainability problem, belief in practicing their profession in a sustainable way, and their qualification to practice a more sustainable construction are increased or strengthened (Soria et al. 2013).

\section{Sustainability Education in Construction}

In general, construction related training and education programs in the United States are accredited by the American Council for Construction Education (ACCE) or the Accreditation Board for Engineering and Technology (ABET). The ACCE is mainly focused on construction education programs to accredit at the associate, bachelor's and master's degree levels. ACCE accreditation is generally reflected and served for the interest of three parties: (1) students, (2) the construction industry, and (3) owners/users of constructed facilities and the public at large (ACCE n.d.). The ABET has many different accredited programs in the disciplines of the applied and natural sciences, computing, engineering, and engineering technology at the associate, bachelor's and master's degree levels. ABET construction-related programs have maintained its accreditation under engineering programs by the Engineering Accreditation Commission (EAC) or engineering technology programs by the Engineering Technology Accreditation Commission (ETAC) (ABET n.d.). Due to the tremendous expansion of the USGBC and its LEED program in recent years, both accrediting agencies include environmental coursework with its approved curriculum (Tinker and Burt 2004). ACCE guidelines even mandate that environmental issues and sustainable construction be covered as parameters affecting project planning (ACCE n.d.). Most of the course structure is generally based on sustainable building practices. Students can explore the green building strategies used in the design as well as the construction of sustainable buildings including site selection, water efficiency, energy, materials/resources, and indoor environmental quality using traditional instruction methods. Although the course provides a general concept of the sustainability at the beginning of the class, most class materials only offer to identify the major environmental and resource concerns that precipitate the sustainable building movements and explain their impacts, rather than social responsibility. 


\section{Methods}

\subsection{Sample Collection}

The data for this research were collected by conducting a survey from two regional universities located in the southern United States. Both universities are accredited by the ACCE, and sample data were collected via a questionnaire that was handed out during randomly selected classes, excluding sustainability classes. University A has offered a sustainability course at a senior level called Green Building and Sustainable Construction. Forty-seven respondents were from the upper level classes at university A and represented 50\% of the senior level population approximately in the Construction Management Program. Forty-eight respondents at university B were mainly from two programs, Civil Engineering and Construction Management, and represented 35\% of the population approximately from two programs.

This survey was approved as a human subject exempt research by the Institutional Review Board (IRB) that an administrative body established to protect the rights and welfare of human research subjects and a total of 95 students participated in the survey. According to Cohen's study (Cohen 1992), a sample size of 92 respondents is associated with an effect size that falls between medium and large. A sample size of 95 would be reasonable when assuming a significance level of $5 \%$ and a power of $80 \%$. All data collected from the respondents were used to measure the constructs in our study. Forty-two students from the sample had taken sustainability courses at the university level, and most students were familiar with the concept of sustainability although many of them had not taken any sustainability courses prior to completing the survey.

\subsection{Questionnaire Design}

The questionnaire consisted of three major parts. Part 1 of the questionnaire contained several questions about the respondent's general information including their current academic standing, gender, major, age, and green project involvement (i.e., whether they have experience in any sustainability projects). Part 2 of the questionnaire which was divided into three sections was created to examine an individual's level of environmental concerns and sustainability knowledge. The first section in Part 2 inquired about his/her experience of taking any sustainability courses and measured the level of environmental concerns. The second section consisted of test items related to sustainable construction in order to assess objective knowledge acquired from taking the sustainable construction course. The third section was designed to examine the respondent's subjective knowledge, that is, the individual's evaluation of his/her own knowledge. Objective knowledge is generally defined as the correct information stored in individual's memory reflecting how much they truly know about a given topic and subjective knowledge (also known as self-assessed knowledge) as their own evaluation of how much they know (Park et al. 1994). Part 3 of questionnaire explored respondents' sustainable behaviors as consumers to examine whether engaging in sustainable education has an effect on adopting sustainable purchase behaviors.

All items in Part 2 and 3 were based on seven-point Likert scales (e.g., 1 = strongly disagree to $7=$ strongly agree or 1 = very unconcerned to $7=$ very concerned, depending on the type of question) excluding objective knowledge items in Part 2. Objective knowledge test consisted of true/false and multiple choice questions related to the topic. 


\section{Results}

\subsection{Part 1: Respondent Information}

According to the Construction Chart Book (CPWR 2018) that characterizes the changing construction industry and its workers in the United States, only 9.2 percent of construction workers were female, and 80.4 percent of them were in the managerial or support staff positions in 2015. In line with this finding, our sample mainly consisted of males which were 91.58 percent of our total respondents (Table 1). In addition, the sample gender distribution reflected the gender imbalance in universities because construction or engineering major students are predominantly male. Among our sample, 79 students were majoring in construction management, nine students in civil engineering, five students in airport management and development, and two students chose not to reveal their major. Overall, $96.84 \%$ of the students answered that they had heard about the concept of sustainability. Regarding Grade Point Average (GPA), nine students did not want to indicate their GPA, and none had a GPA less than 2.0. The predominant age group was from 20 to $22(62.11 \%)$. Almost half of the students did not have any construction work experience $(48.42 \%)$. For this reason, only a limited number of students had been involved in a green building project previously.

Table 1. Sample characteristics.

\begin{tabular}{|c|c|c|}
\hline & Frequency & $\%$ \\
\hline \multicolumn{3}{|l|}{ Gender } \\
\hline Male & 87 & 92 \\
\hline Female & 8 & 8 \\
\hline \multicolumn{3}{|l|}{ Age } \\
\hline 19 or younger & 7 & 7 \\
\hline $20-22$ & 59 & 62 \\
\hline $23-27$ & 22 & 23 \\
\hline $28-39$ & 6 & 6 \\
\hline $40-55$ & 1 & 1 \\
\hline \multicolumn{3}{|l|}{ Student Classification } \\
\hline Freshman & 2 & 2 \\
\hline Sophomore & 13 & 14 \\
\hline Junior & 22 & 23 \\
\hline Senior & 48 & 51 \\
\hline Graduate student & 9 & 9 \\
\hline Other & 1 & 1 \\
\hline \multicolumn{3}{|l|}{ Grade Point Average (GPA) } \\
\hline Less than 2.0 & 0 & 0 \\
\hline $2.0-2.49$ & 18 & 19 \\
\hline $2.50-2.99$ & 33 & 35 \\
\hline $3.00-3.49$ & 26 & 27 \\
\hline $3.5-4.0$ & 9 & 9 \\
\hline No response & 9 & 9 \\
\hline \multicolumn{3}{|l|}{ Major } \\
\hline Airport management and development & 5 & 5 \\
\hline Civil engineering & 9 & 9 \\
\hline Construction management & 79 & 83 \\
\hline No response & 2 & 2 \\
\hline $\begin{array}{l}\text { Working experience in the construction } \\
\text { industry }\end{array}$ & $\begin{array}{l}\text { mean: } 2.65 \\
\text { years }\end{array}$ & $\begin{array}{l}\text { SD: } \\
7.19\end{array}$ \\
\hline
\end{tabular}




\subsection{Part 2: Environmental Concern and Sustainability Knowledge}

The second part of the questionnaire was developed to gain information on respondents' level of concerns about the environment and sustainability knowledge. It consisted of three sections: (1) environmental concern, (2) objective knowledge, and (3) subjective knowledge.

\subsubsection{Environmental Concern}

The results showed that 92 respondents (96.84\%) recognized the concept of sustainability. Three students who did not understand the concept had not taken any sustainable construction courses before. $44 \%$ of the students responded that they had taken a sustainable construction course which is related to green building practices. The remaining $56 \%$ of the respondents had not taken the sustainable construction course, which may be attributed to the fact that the course is generally offered as an elective course at a junior or senior level in their curriculum.

Results of environmental concern including individual's concern about the environment in general, water and air pollution, and extravagant water usage are shown in Table 2. Most respondents expressed high levels of concerns selecting from 4 to 7 mainly on all questions from the 7-point Likert scale. The mean scores were $5.02(\mathrm{SD}=1.38), 5.26(\mathrm{SD}=1.37)$, and $4.85(\mathrm{SD}=1.60)$ for general environment, water and air pollution, and extravagant water usage, respectively.

Table 2. Means of environmental concern items.

\begin{tabular}{lccc}
\hline \multicolumn{1}{c}{ Environmental Concern Items } & \multicolumn{3}{c}{ Mean (SD) } \\
\cline { 2 - 4 } & With Education & Without Education & Combined \\
\hline $\begin{array}{l}\text { General environment: How } \\
\begin{array}{l}\text { concerned are you about the } \\
\text { environment? }\end{array}\end{array}$ & $5.74(1.48)$ & $5.02(1.38)$ \\
\hline $\begin{array}{l}\text { Water and air pollution: How } \\
\text { concerned are you about water and } \\
\text { air pollution in your city? }\end{array}$ & $5.08(1.50)$ & $5.50(1.15)$ & $5.26(1.37)$ \\
\hline $\begin{array}{l}\text { Extravagant water usage: How } \\
\text { concerned are you about extravagant } \\
\text { water usage in your city? }\end{array}$ & $4.64(1.77)$ & $5.12(1.33)$ & \\
\hline
\end{tabular}

Table 3 and Figure 1 show the difference in environmental concern items between students who had engaged in sustainable education and students who had not. An independent two-sample $t$-test was conducted to compare the scores between the two groups. Statistical results showed that the level of environmental concerns of students who had engaged in sustainable education $(\mathrm{M}=4.82, \mathrm{SD}=1.36)$ were significantly lower than that of students who had not $(\mathrm{M}=5.33, \mathrm{SD}=1.04) ; t(92)=2.09, p=0.04$.

Table 3. Comparison of environmental concern between groups.

\begin{tabular}{|c|c|c|c|c|c|c|}
\hline Variable & Mea & (SD) & $95 \%$ CI & $\begin{array}{l}t \text {-Statistic } \\
\text { (df) }\end{array}$ & $p$-Value & $\begin{array}{l}\text { Cronbach's } \\
\text { Alpha }\end{array}$ \\
\hline \multirow{2}{*}{$\begin{array}{l}\text { Environmental } \\
\text { concern }\end{array}$} & $\begin{array}{c}\text { With } \\
\text { education }\end{array}$ & $\begin{array}{l}\text { Without } \\
\text { education }\end{array}$ & \multirow[t]{2}{*}{$(0.03,1.01)$} & \multirow[t]{2}{*}{$2.09(92)$} & \multirow[t]{2}{*}{0.04} & \multirow[t]{2}{*}{0.83} \\
\hline & $5.33(1.04)$ & $4.82(1.36)$ & & & & \\
\hline
\end{tabular}




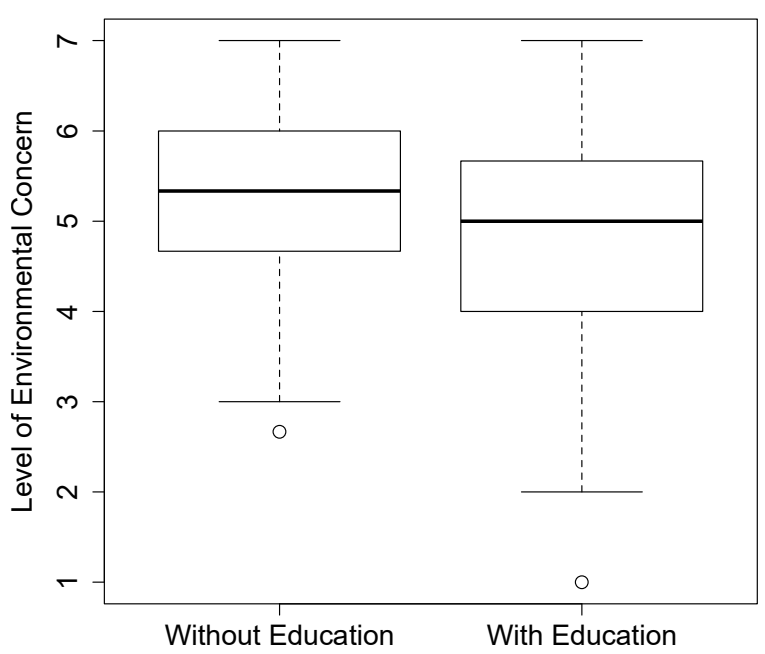

Figure 1. Statistical distribution of level of environmental concern.

\subsubsection{Objective Knowledge}

The second section measured students' knowledge retention using true/false and multiple choice questions. Items that were used for objective knowledge were directly taken from the LEED Green Associate Exam Prep Course-Sample Questions from USGBC in Illinois Chapter. These items were chosen by three experts in the field to ensure that the test contents involve major concepts that should be covered in sustainability courses in construction. The overall result was disappointing even considering the fact that $56 \%$ of students had not taken a sustainable construction course. On average, students were only $52.1 \%$ correct in the test. Furthermore, no statistical evidence was found to claim that taking a sustainability course has an effect on enhancing students' knowledge on sustainability-related topics. As seen in Table 4 and Figure 2, the independent two-sample $t$-test results indicated that the difference between students who had engaged in sustainable education, $\mathrm{M}=0.53, \mathrm{SD}=0.27$, and students who had not, $\mathrm{M}=0.51, \mathrm{SD}=0.20$, was insignificant, $t(92)=-0.57, p=0.57$. This insignificant difference in objective knowledge scores may have been resulted from the limited number of questions used for the test to assess students' objective knowledge level. However, the results were unexpected as the questions were directly related to the specific information needed to pass the LEED Green Associates exam and limited to LEED certification rather than general sustainable construction education.

\subsubsection{Subjective Knowledge}

Four items were used to measure respondents' self-assessed knowledge and familiarity toward sustainable design and construction for USGBC LEED, Green Globe, and Envision. The results are shown in Table 5. In contrast to responses reported previously for environmental concern, the distribution of subjective knowledge was found to be skewed toward low scores. Respondents expressed a lack of familiarity with the topic by mostly selecting from 2 to 4 from the 7-point Likert scale. Respondents seem to have low confidence in the area of sustainable design and construction as evidenced by an average score of 3.52 of subjective knowledge.

Table 4. Comparison of objective knowledge between groups.

\begin{tabular}{cccccc}
\hline Variable & \multicolumn{2}{c}{ Mean (SD) } & $\mathbf{9 5 \% ~ C I}$ & t-Statistic (df) & $p$-Value \\
\hline $\begin{array}{c}\text { Objective } \\
\text { knowledge }\end{array}$ & With education & Without education & $(-0.12,0.07)$ & $-0.57(92)$ & 0.57 \\
\cline { 2 - 3 } & $0.53(0.27)$ & $0.51(0.20)$ & & & \\
\hline
\end{tabular}




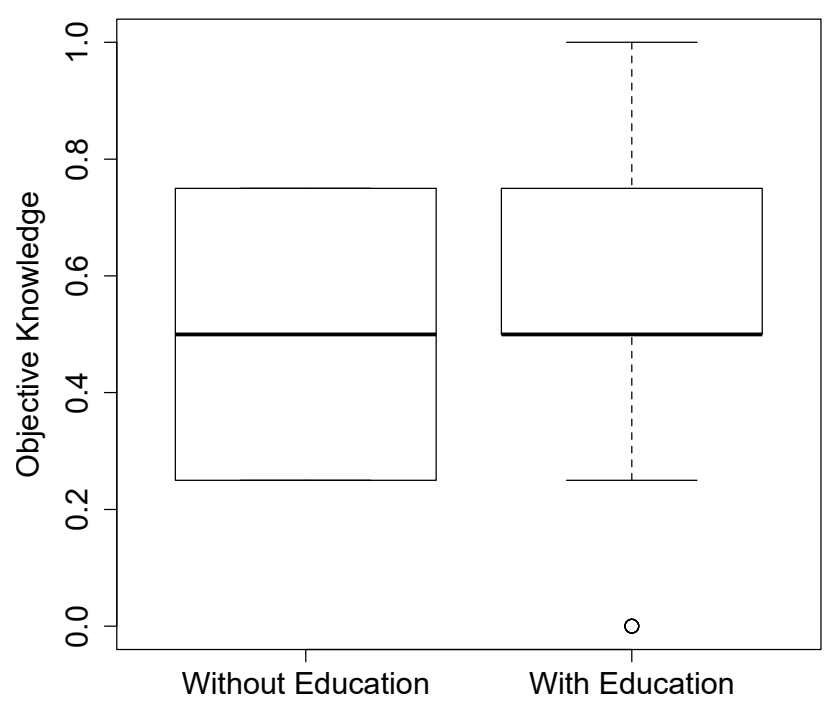

Figure 2. Statistical distribution of objective knowledge.

Table 5. Means of subjective knowledge items. LEED: Leadership in Energy and Environmental Design; USGBC: United States Green Building Council.

\begin{tabular}{|c|c|c|c|}
\hline \multirow{2}{*}{ Subjective Knowledge Items } & \multicolumn{3}{|c|}{ Mean (SD) } \\
\hline & With Education & Without Education & Combined \\
\hline $\begin{array}{l}\text { Subjective Knowledge 1: What is your } \\
\text { level of knowledge in sustainable design } \\
\text { and construction? }\end{array}$ & $2.91(1.40)$ & $3.69(0.98)$ & $3.25(1.29)$ \\
\hline $\begin{array}{l}\text { Subjective Knowledge 2: Are you familiar } \\
\text { with sustainability (i.e., USGBC, LEED, } \\
\text { Green Globe, Envision)? }\end{array}$ & $3.23(1.75)$ & $4.86(1.49)$ & $3.95(1.82)$ \\
\hline $\begin{array}{l}\text { Subjective Knowledge 3: Are you } \\
\text { confident in your level of knowledge in } \\
\text { the areas of sustainable design and } \\
\text { construction (i.e., USGBC, LEED, Green } \\
\text { Globe, Envision)? }\end{array}$ & $2.74(1.56)$ & $3.76(1.27)$ & $3.19(1.52)$ \\
\hline $\begin{array}{l}\text { Subjective Knowledge 4: Are you } \\
\text { confident that you could communicate } \\
\text { sustainable strategies and technologies in } \\
\text { construction with others? }\end{array}$ & $3.09(1.70)$ & $4.24(1.43)$ & $3.60(1.68)$ \\
\hline
\end{tabular}

Differences in subjective knowledge items between students who had engaged in sustainable education and students who had not been presented in Table 6 and Figure 3. Similar to the previous sections, an independent two-sample $t$-test was conducted to compare subjective knowledge scores between the two student groups. There was a significant difference in subjective knowledge of students who had engaged in sustainable education $(\mathrm{M}=2.99, \mathrm{SD}=1.35)$ and students who had not $(\mathrm{M}=4.14$, $\mathrm{SD}=0.99) ; t(92)=4.78, p<0.001$. Interestingly, the results suggested that students who had not taken any course related to sustainable construction had higher levels of subjective knowledge than students who had. This finding implies that prior experience of sustainable construction education does not have a positive effect on improving students' level of familiarity and confidence related to the topic. The correlation between objective and subjective knowledge was insignificant, $\mathrm{r}=-0.14, p=0.19$, which implies that how much an individual actually knows is not significantly related to how much an individual thinks he/she knows. 
Table 6. Comparison of subjective knowledge between groups.

\begin{tabular}{|c|c|c|c|c|c|c|}
\hline Variable & \multicolumn{2}{|c|}{ Mean (SD) } & $95 \% \mathrm{CI}$ & $\begin{array}{l}t \text {-Statistic } \\
\text { (df) }\end{array}$ & $p$-Value & $\begin{array}{c}\text { Cronbach's } \\
\text { Alpha }\end{array}$ \\
\hline \multirow{2}{*}{$\begin{array}{l}\text { Subjective } \\
\text { Knowledge }\end{array}$} & With Education & Without Education & \multirow{2}{*}{$(0.67,1.62)$} & \multirow{2}{*}{$4.78(92)$} & \multirow{2}{*}{$<0.001$} & \multirow{2}{*}{0.86} \\
\hline & $2.99(1.35)$ & $4.14(0.99)$ & & & & \\
\hline
\end{tabular}

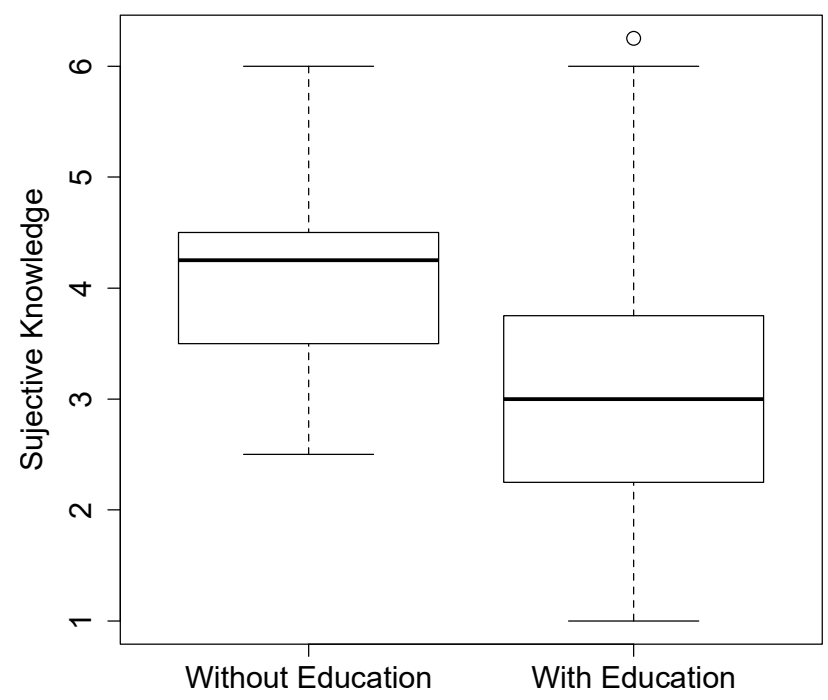

Figure 3. Statistical distribution of subjective knowledge.

\subsection{Part 3: Sustainable Consumer Behavior}

Sustainable consumer behavior generally refers to taking into consideration the public consequences of consumption or making an effort to use one's purchasing power to make a social change (Webster 1975). This study examined whether students' experience of being involved in sustainability education will positively influence their ethical behaviors, for instance, being more open to adopt ethical purchase behaviors. This was based on the belief that any academic curriculum which is ultimately related to sustainability will have the potential to influence an individual's behaviors and attitudes towards the environmental movement. Items were developed to measure sustainable consumer behavior based on those used in previous research (Stern et al. 1999). These items measure self-reported behaviors of individual's sustainable consumption. The means of four items are presented in Table 7.

An independent two-sample $t$-test was conducted to compare sustainable consumer behavior between students who had engaged in sustainable education and students who had not. Similar to the unexpected results in the previous sections including level of environmental concerns and subjective knowledge, statistical results showed that the scores of sustainable consumer behavior for students who had engaged in sustainable education $(\mathrm{M}=3.17, \mathrm{SD}=1.46)$ were significantly lower than those of students who had not $(\mathrm{M}=3.78, \mathrm{SD}=1.29) ; t(92)=2.16, p=0.03$ (Table 8 and Figure 4 ). 
Table 7. Means of sustainable consumer behavior items.

\begin{tabular}{lccc}
\hline \multirow{2}{*}{ Sustainable Consumer Behavior Items } & & Mean (SD) & \\
\cline { 2 - 4 } & With Education & Without Education & Combined \\
\hline $\begin{array}{l}\text { Sustainable Consumer Behavior 1: How } \\
\text { often do you make a special effort to buy } \\
\text { fruits and vegetables grown without } \\
\text { pesticides or chemicals; also known as }\end{array}$ & $3.13(1.64)$ & $4.05(1.68)$ & $3.54(1.71)$ \\
organic fruits and vegetables? & & & \\
\hline $\begin{array}{l}\text { Sustainable Consumer Behavior 2: How } \\
\text { often do you make a special effort to buy } \\
\text { paper and plastic products that are made } \\
\text { from recycled materials? }\end{array}$ & $3.04(1.72)$ & $3.74(1.53)$ & 3.35 (1.67) \\
\hline $\begin{array}{l}\text { Sustainable Consumer Behavior 3: How } \\
\text { often do you avoid buying products from a } \\
\text { company that you know may be harming } \\
\text { the environment? }\end{array}$ & $3.15(1.74)$ & $3.71(1.70)$ & $3.40(1.74)$ \\
\hline $\begin{array}{l}\text { Sustainable Consumer Behavior } 4: \text { How } \\
\text { often do you make a special effort to buy } \\
\text { household chemicals such as detergent and } \\
\text { cleaning solutions that are environmentally } \\
\text { friendly? }\end{array}$ & $3.36(1.81)$ & & \\
\hline
\end{tabular}

Table 8. Comparison of sustainable consumer behavior between groups.

\begin{tabular}{|c|c|c|c|c|c|c|}
\hline Variable & \multicolumn{2}{|c|}{ Mean (SD) } & $95 \%$ CI & $\begin{array}{l}t \text {-Statistic } \\
\text { (df) }\end{array}$ & $p$-Value & $\begin{array}{c}\text { Cronbach's } \\
\text { Alpha }\end{array}$ \\
\hline \multirow{2}{*}{$\begin{array}{c}\text { Sustainable } \\
\text { Consumer } \\
\text { Behavior }\end{array}$} & With & Without & \multirow{2}{*}{$(0.05,1.17)$} & \multirow{2}{*}{$2.16(92)$} & \multirow{2}{*}{0.03} & \multirow{2}{*}{0.84} \\
\hline & $3.17(1.46)$ & $3.78(1.29)$ & & & & \\
\hline
\end{tabular}

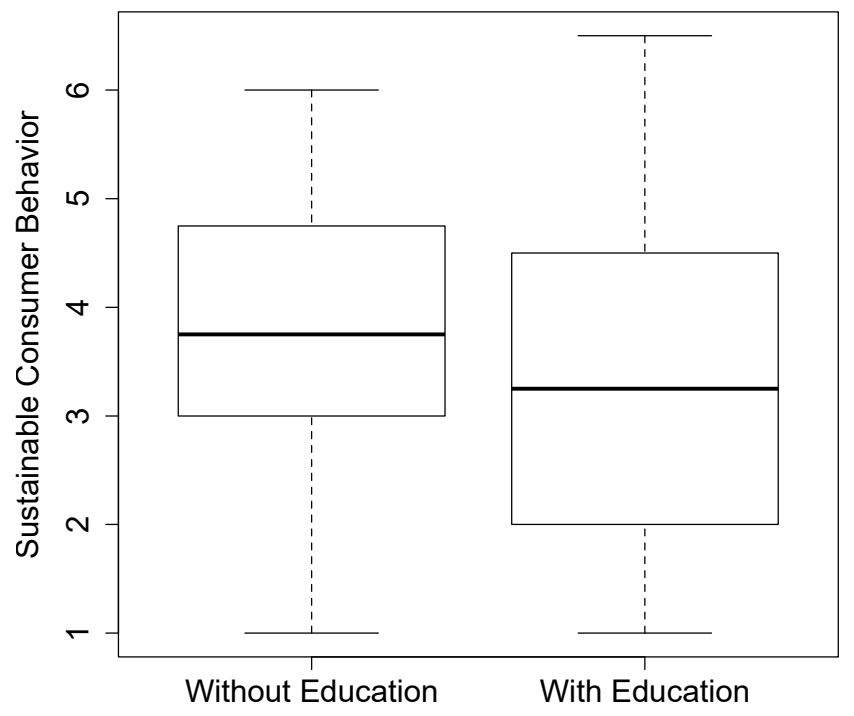

Figure 4. Statistical distribution for sustainable consumer behavior.

\section{Discussion}

The environment is a major concern in communities around the world due to our growing awareness of global warming, climate change, air pollution, desertification, and the loss of biodiversity. Considerable efforts are being devoted to encouraging the adoption of the concept of sustainability to minimize our impact on the environment and maximize the resulting social and economic benefits. 
In light of the challenges and issues associated with construction activities, the building industry has begun to develop more sustainable construction methods. Many construction-related programs in the United States are also developing and offering courses that highlight sustainable design and construction practices. In spite of the growing interest, very little has been known about the effects of sustainability education on students' perception of related issues. Understanding college students' perceptions of sustainability is important because they will soon become the generation that is responsible for driving the economy and maintaining a sustainable society (Jeong et al. 2015).

This study examined sustainable behaviors and social responsibility perceptions among U.S. university students enrolled in construction-related courses. In an attempt to measure the effectiveness of sustainable construction courses and learning outcomes, this study categorized students based on their experience of taking such course(s) and compared the results in terms of their level of environmental concerns, objective and subjective knowledge, and sustainable consumer behaviors.

Sustainable construction education is not limited to delivering information about green building strategies used in the design and construction of sustainable buildings, but it also incorporates general sustainability knowledge. Therefore, it was initially expected that students who had taken the course would have greater levels of environmental concern and be more engaged in performing sustainable consumer behaviors. However, the results were opposite to our initial belief; environmental concern and sustainable consumer behavior scores were significantly lower among students who had taken the course than among those who had not. The findings imply that the current sustainable construction education offered in engineering-related majors has limited effects on motivating students' environmental attitude and behaviors. Perhaps, it needs to put more focus on incorporating general sustainability principles and ethical concepts along with delivering domain specific knowledge and its implementation in the construction industry. It is crucial to obtain technical knowledge of sustainability as a construction professional, but students also need to understand the original concept of sustainability that can inspire individuals and organizations to become better environmental stewards and create a positive social impact.

Regarding the results of two types of knowledge, both objective and subjective knowledge scores were relatively low in our sample. There was no difference between the two groups in the objective knowledge scores and unexpectedly, subjective knowledge scores were significantly lower among students who had taken the course as compared to those who had not. This means that those who have not been engaged in sustainability education feel more familiar with the topic than those who have actually had the opportunity to learn about the subject. When examining the relationship between subjective and objective knowledge, the results show that they are not significantly correlated, which suggests that a student who believes he/she is knowledgeable about sustainability issues in construction does not, in fact, possess the accurate knowledge. The findings regarding the two types of knowledge in this study are similar to the findings in Ellen's (1994) study that showed that not only was objective knowledge about pro-ecological behaviors generally low among university students, but it had an insignificant relationship with subjective knowledge. The limited relationship between the two knowledge types deserves further attention. The complexity of understanding sustainability concepts may have caused students to lose confidence and familiarity about the topic. Further examination is needed to understand students' perception in this area. Moreover, as the two constructs appear to be distinct measures of knowledge, it would be meaningful to see which type of knowledge has a stronger influence on performing sustainable behaviors including engaging in socially responsible activities as industry professionals as well as performing other general behaviors that enhance the well-being of our environment and society.

Fransson and Gärling (1999) suggest that a necessary condition for performing sustainable behaviors is an increased level of knowledge about the negative effects and consequences of environmental deterioration. Thus, sustainability education will be of great importance to help improve students' engagement in sustainable behaviors by providing necessary information to them. According to the findings of this study, the current sustainability courses do not appear to improve 
students' sustainability knowledge and their familiarity level on the topic. The findings suggest that the current sustainable education offered in U.S. engineering and technology programs is in need for further enhancement. Educators may consider redesigning the courses so that they accurately embody a rigorous set of study units that are aligned with industry needs and increase student's objective knowledge level. Furthermore, these courses should be developed to be adaptable to the diverse needs of students to create an engaging learning environment. By offering relevant academic contents and activities, students may increase their level of subjective knowledge, in other words, feel more familiar with and confident in the topic as a result of taking the course.

Perhaps, taking only one sustainability course may have not significantly influenced student perceptions or outcomes. There are multiple ways to integrate sustainability in higher education. For example, Lozano (2006) suggested a narrow and broad approach involving individual program specific and university-wide or cross-disciplinary requirements, respectively. In addition, Rusinko (2010) presented a model of how sustainability can be integrated into higher education curricula. There were four options in her model: integration of sustainability education within existing courses as a new topic or module; integrating it into common course requirement across the university; creating a new discipline-specific program, major, minor, or course; and creating a new cross-disciplinary course, program, major, minor, or course. Faculty and administrators need to closely examine their objectives and student needs and identify the best option to make better strategic decisions regarding sustainability education. This study used a narrow focus of testing the effect of taking program-specific sustainability course(s) which seems to be a more common approach of adopting the sustainability in most construction-related programs in U.S. universities. Although institutions of higher education are investigating ways to incorporate sustainability into their curricula, extremely limited information is offered concerning their effects, particularly based on distinctive ways sustainability is incorporated into their curricula. Considering the growing number of sustainability courses and programs that are being developed, it would be important to investigate this topic in higher education where should be focused.

While this study made contributions by offering information about the effects of sustainability education on students' perception and outcome, it has several limitations that can provide suggestions for future studies. First, this study incorporated a posttest only design which is susceptible to internal validity threats. Students were assessed once after taking the sustainability course and their pre-existing knowledge and attitudes about environmental issues may have had an influence on their posttest scores. Future studies could include a pretest that can be used to assess the equivalency of groups prior to taking the course. Another limitation involves the items that were used to measure constructs of this study. For example, the measure of sustainable consumer behavior is based on self-reports that may not truly reflect one's actual behaviors. Furthermore, there were only four items to measure this construct, which may not be sufficient to provide an overall depiction of students' purchasing behaviors. Future studies can measure behaviors in diverse areas of sustainable buying from observation or previous purchase history to reduce social desirability bias and enhance the validity of the measurement.

Author Contributions: Y.J. designed the study, prepared the original draft, and provided editing, K.P. performed the statistical analyses and review, and J.A. collected data and contributed to writing the paper.

Funding: This research received no external funding.

Conflicts of Interest: The authors declare no conflict of interest.

\section{References}

Accreditation Board for Engineering and Technology (ABET). n.d. Available online: https://www.abet.org/ (accessed on 5 February 2019).

American Council for Construction Education (ACCE). n.d. Available online: https://www.acce-hq.org/ (accessed on 5 February 2019). 
Aertsens, Joris, Koen Mondelaers, Wim Verbeke, Jeroen Buysse, and Guido Van Huylenbroeck. 2011. The influence of subjective and objective knowledge on attitude, motivations and consumption of organic food. British Food Journal 113: 1353-78. [CrossRef]

Bamberg, Sebastian, and Guido Möser. 2007. Twenty years after Hines, Hungerford, and Tomera: A new meta-analysis of psycho-social determinants of pro-environmental behaviour. Journal of Environmental Psychology 27: 14-25. [CrossRef]

Benn, Suzanne, and Dexter Dunphy. 2009. Action research as an approach to integrating sustainability into MBA programs: An exploratory study. Journal of Management Education 33: 276-95. [CrossRef]

Cohen, Jacob. 1992. A power primer. Psychological Bulletin 112: 155-59. [CrossRef] [PubMed]

Center for Construction Research and Training (CPWR). 2018. Labor Force Characteristics-Women Workers in Construction and Other Industries Occupations in Construction. In The Construction Chart Book, 6th ed. Silver Spring: CPWR, Available online: https:/ /www.cpwr.com/chart-book-6th-edition-laborforce-characteristics-women-workers-construction-and-other-industries (accessed on 1 January 2019).

Davidson, P., and R. W. Griffin. 2000. Management: Australia in a Global Context. Milton: John Wiley \& Sons Australia.

Ellen, Pam Scholder. 1994. Do we know what we need to know? Objective and subjective knowledge effects on pro-ecological behaviors. Journal of Business Research 30: 43-52. [CrossRef]

Figueiró, Paola Schmitt, and Emmanuel Raufflet. 2015. Sustainability in higher education: A systematic review with focus on management education. Journal of Cleaner Production 106: 22-33. [CrossRef]

Fransson, Niklas, and Tommy Gärling. 1999. Environmental concern: Conceptual definitions, measurement methods, and research findings. Journal of Environmental Psychology 19: 369-82. [CrossRef]

Future Earth. 2014. Future Earth 2025 Vision. Available online: http:/ / www.futureearth.org/sites/default/files / future-earth_10-year-vision_web.pdf (accessed on 4 February 2019).

Holm, Tove, Kaisu Sammalisto, Thomas S. Grindsted, and Timo Vuorisalo. 2015. Process framework for identifying sustainability aspects in university curricula and integrating education for sustainable development. Journal of Cleaner Production 106: 164-74. [CrossRef]

Jeong, Michael Myung, Younghan Jung, and Dan Daehyun Koo. 2015. College Students' Perceptions of Sustainability: A Regional Survey. Journal of Building Construction and Planning Research 3: 209-20. [CrossRef]

Kevern, John T. 2011. Green building and sustainable infrastructure: Sustainability education for civil engineers. Journal of Professional Issues in Engineering Education and Practice 137: 107-12. [CrossRef]

Libra, Judy A. 2007. Environmental process engineering: Building capacity for sustainability. Journal of Professional Issues in Engineering Education and Practice 133: 308-19. [CrossRef]

Lidgren, Alexander, Håkan Rodhe, and Don Huisingh. 2006. A systemic approach to incorporate sustainability into university courses and curricula. Journal of Cleaner Production 14: 797-809. [CrossRef]

Lozano, Rodrigo. 2006. Incorporation and institutionalization of SD into universities: Breaking through barriers to change. Journal of Cleaner Production 14: 787-96. [CrossRef]

Mihelcic, James R., John C. Crittenden, Mitchell J. Small, David R. Shonnard, David R. Hokanson, Qiong Zhang, Hui Chen, Sheryl A. Sorby, Valentine U. James, John W. Sutherl, and et al. 2003. Sustainability science and engineering: the emergence of a new metadiscipline. Environmental Science \& Technology 37: 5314-24.

O’Byrne, David, Weston Dripps, and Kimberly A. Nicholas. 2015. Teaching and learning sustainability: An assessment of the curriculum content and structure of sustainability degree programs in higher education. Sustainability Science 10: 43-59. [CrossRef]

Park, C. Whan, David L. Mothersbaugh, and Lawrence Feick. 1994. Consumer knowledge assessment. Journal of Consumer Research 21: 71-82. [CrossRef]

Richards, Jennie. 2012. Sustainable Industry Sector Retrospectives. Available online: http: / / enviroinstitute.org/wp-content/uploads/2012/09/GREEN-BUILDING-A-Retrospective-History-ofLEED-Certification-November-2012.pdf (accessed on 1 November 2018).

Roome, Nigel. 2005. Teaching sustainability in a global MBA: Insights from the OneMBA. Business Strategy and the Environment 14: 160-71. [CrossRef]

Rusinko, Cathy A. 2007. Green manufacturing: An evaluation of environmentally sustainable manufacturing practices and their impact on competitive outcomes. IEEE Transactions on Engineering Management 54: 445-54. [CrossRef] 
Rusinko, Cathy A. 2010. Integrating sustainability in higher education: A generic matrix. International Journal of Sustainability in Higher Education 11: 250-59. [CrossRef]

Sammalisto, Kaisu, and Thomas Lindhqvist. 2008. Integration of sustainability in higher education: A study with international perspectives. Innovative Higher Education 32: 221-33. [CrossRef]

Soria, Beatriz Rodríguez, José M. Pérez Bella, Javier Domínguez Hernández, Enrique Cano Suñén, and Juan J. del Coz Díaz. 2013. Education for sustainable development: Methodology and application within a construction course. Journal of Professional Issues in Engineering Education and Practice 139: 72-79. [CrossRef]

Stern, Paul C., Thomas Dietz, Troy Abel, Gregory A. Guagnano, and Linda Kalof. 1999. A value-belief-norm theory of support for social movements: The case of environmentalism. Human Ecology Review 6: 81-97.

Strategic Imperatives-UN. 1987. Report of the World Commission on Environment and Development: Our Common Future. Available online: http://www.un-documents.net/our-common-future.pdf (accessed on 1 January 2019).

Sullivan, James, and Russell Walters. 2013. Integrating Sustainability Curriculum into Construction Education: A Progress Report. Journal of Sustainability Education 5: 1-9.

Tinker, Audrey, and Richard Burt. 2004. Greening the Construction Curriculum. International Journal of Construction Education and Research 1: 26-33.

U.S. Green Building Council. 2015. Better Buildings Are Our Legacy. Available online: https://new.usgbc.org/ (accessed on 1 December 2018).

Webster, Frederick E., Jr. 1975. Determining the characteristics of the socially conscious consumer. Journal of Consumer Research 2: 188-96. [CrossRef]

(C) 2019 by the authors. Licensee MDPI, Basel, Switzerland. This article is an open access article distributed under the terms and conditions of the Creative Commons Attribution (CC BY) license (http://creativecommons.org/licenses/by/4.0/). 